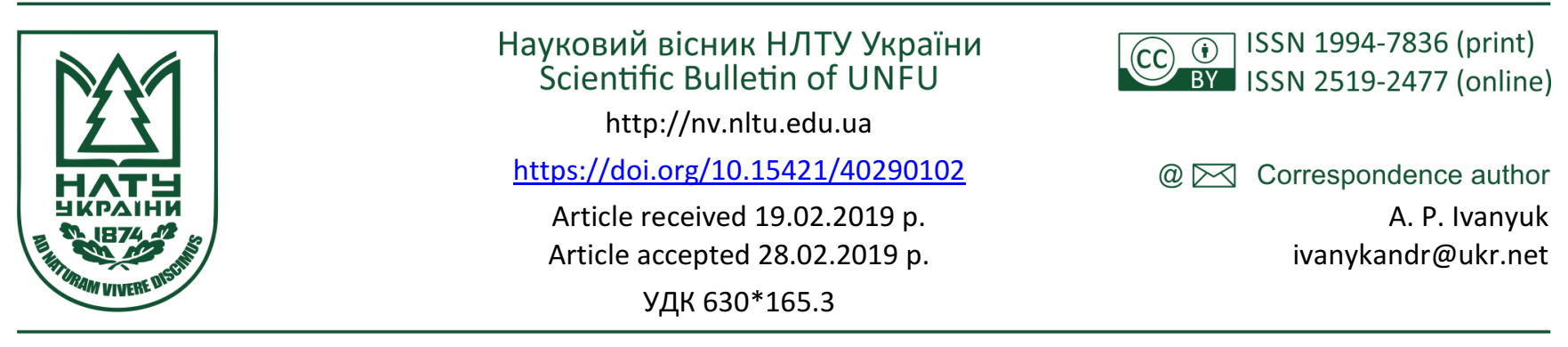

А. П. Іванюк, Т. І. Харачко, Є. П. Іванцов

Національний лісотехнічний університет Украйни, м. Львів, Украйна

\title{
СХОЖІСТЬ НАСІННЯ ТА БІОМЕТРИЧНІ ПОКАЗНИКИ ПЛОДІВ ПАВЛОВНІЇ ПОВСТИСТОЇ PAULOWNIA TOMENTOSA STEUD. РІЗНОГО ГЕОГРАФІЧНОГО ПОХОДЖЕННЯ
}

\begin{abstract}
Наведено результати дослідження біометричних показників плодів та насіння Paulownia tomentosa Steud., заготовлених із дерев, що зростають у грунтово-кліматичних умовах Одеської, Закарпатської та Львівської областей. Встановлено, що в умовах Одеської області павловнія повстиста формує більші плоди. Насіння цього походження характеризується значною швидкістю проростання та дружністю появи сходів. Досліджено вплив змінного температурного режиму пророщування на посівні якості насіння різного географічного походження. Встановлено, що зниження температури пророщування спричиняє зменшення енергії проростання, лабораторної та абсолютної схожості насіння, збільшує середній насінний спокій. Оцінено вплив тривалості попереднього намочування на схожість насіння. Виявлено, що попереднє намочування насіння істотно підвищує показники схожості, його тривалість пов'язується з показниками енергії проростання, технічної та абсолютної схожості. Встановлено, що серед трьох походжень насіння найвища технічна схожість характерна для насіння з Львівської області. Насіння з Одеської області має найвищу енергію проростання. Загалом досліджуване насіння всіх трьох походжень характеризується високими посівними якостями, що свідчить про можливість використання районованого насіння для вирощування садивного матеріалу і створення насаджень 3 притаманною для материнських рослин біологічною стійкістю, зокрема до впливу низьких температур у конкретних грунтово-кліматичних умовах.
\end{abstract}

Ключові слова: Paulownia tomentosa Steud.; насіння; плоди; енергія проростання; технічна схожість; абсолютна схожість; середній насінний спокій.

Вступ. Павловнія повстиста - швидкоросла деревна порода, що є автохтонна для Китаю та Східної Азії (Bojnansky \& Fargasova, 2007; Bonner \& Karrfalt, 2008; Icka, Damo \& Icka, 2016; Kolesnikov, 1974). В Україні вид представлений у ботанічних садах, поодиноко трапляється в зелених насадженнях міст та в озелененні приватних садиб. Завдяки своїм унікальним характеристикам, а саме: швидкому росту, невибагливості до родючості та вологості грунту, засвоєнню значних обсягів двоокису вуглецю з атмосфери, відносній морозостійкості та, головне, здатності регенерувати багато разів після зрізання дерев, породу вже понад 40 років використовують у плантаційному вирощуванні країн Америки, Європи, Азії та Австралії (Hakan \& Kol, 2010; Hugo, et al., 2013; Icka, Damo \& Icka, 2016; Woods, 2008; Kumarmangalam, et al., 2013). Про перспективність плантаційного вирощування породи 3 кількома короткими ротаціями рубань також останнім часом багато говорять і в Україні, оскільки відомо, що швидкість росту та накопичення біомаси другого і наступних поколінь порослевого походження павловнії повстистої є набагато більшою від першого покоління. Це пояснюють властивістю рослин порослевого походження живитись та рости завдяки добре розвиненій кореневій системі

зрубаного дерева (Hakan \& Kol, 2010; Icka, Damo \& Icka, 2016; Woods, 2008; Kumarmangalam, et al., 2013; Zhu, Chao, Lu \& Gao, 1986).

На території сучасної України павловнія повстиста вперше з'явилася у Нікітському ботанічному саду ще в 1846 р. Пізніше інтродуцент почали успішно культивувати у південних областях України і тепер можна говорити про акліматизацію виду на цій території (Kolesnikov, 1974). Сьогодні павловнія повстиста поширена в різних регіонах України. Інтродуцент успішно зростає у Закарпатській та Львівській областях (Kolesnikov, 1974).

Визначали посівні якостей насіння павловнії повстистої багато дослідників (Bojnansky \& Fargasova, 2007; Bonner \& Karrfalt, 2008; Kokhno, et al., 1991). Більшість 3 них відзначають високі значення показників схожості насіння у цієї породи.

Мета роботи - визначити схожість насіння та біометричні показники плодів дерев, які акліматизовані в різних регіонах України. Результати досліджень повинні вказати на можливість використання районованого насіння для вирощування садивного матеріалу і створення насаджень $з$ притаманною для материнських рослин біологічною стійкістю, зокрема до впливу низьких температур, характерних у конкретних грунтово-кліма-

\footnotetext{
Інформація про авторів:

Іванюк Андрій Петрович, канд. с.-г. наук, доцент, кафедра лісових культур і лісової селекції. Email: ivanykandr@ukr.net Харачко Тарас Іванович, канд. с.-г. наук, доцент, кафедра лісових культур і лісової селекції. Email: taraskharachko@nltu.edu.ua Іванцов Євген Петрович, здобувач, кафедра лісових культур і лісової селекції. Email: ivancovgena@ukr.net

Цитування за ДСтУ: Іванюк А. П., Харачко Т. І., Іванцов Є. П. Схожість насіння та біометричні показники плодів павловнії повстистої Paulownia Tomentosa Steud. різного географічного походження. Науковий вісник НлтУ України. 2019, т. 29 , № 1. С. $16-19$.

Citation APA: Ivanyuk, A. P., Harachko, T. I., \& Ivantsov, E. P. (2019). Germination of Seedlings and Biometric Parameters of Fruits of Paulownia Tomentosa Steud. of Different Geographical Origin. Scientific Bulletin of UNFU, 29(1), 16-19. https://doi.org/10.15421/40290102
} 
тичних умовах.

Матеріал і методи дослідження. Визначення біометричних показників здійснювали у плодів, отриманих у різних географічних регіонах України (Львівській, Закарпатській та Одеській областях). Заготівлю плодів проводили у листопаді 2018 р. способом їх обривання $з$ ростучих дерев віком 26-35 років. Під час проведення замірів біометричних показників вибірка дослідження становила 200 плодів 3 одного дерева. Під час дослідження було проведено заміри довжини, діаметра та маси генеративних органів у свіжозібраному стані. Довжину плодів та їхній діаметр визначали за допомогою електронного штангенциркуля (точність до 0,01 мм), а масу - електронною вагою Axsis - 3 точністю зважування 0,001 г та межею зважування 50 г. Діаметр визначали на середині довжини плоду.

Для визначення технічної та абсолютної схожості, енергії проростання, середнього насінного спокою, маси 1000 насінин павловнії повстистої із заготовлених плодів ми отримали насіння і відібрали три окремі зразки 3 дерев, зазначених вище походжень. Насіння було одержане способом перероблення плодів у грудні 2018 р. та зберігалося у сухому прохолодному місці $\left(+3 \ldots 5^{\circ} \mathrm{C}\right)$. Усі лабораторні дослідження проводили у січні 2019 р. у лабораторії лісового насінництва, кафедри лісових культур і лісової селекції НЛТУ України.

Експеримент проводили згідно з чинними в Україні державними стандартами: визначення маси 1000 насінин - ДСТУ 5036:2008 (DSTU 5036:2008, 2009); схожість, енергія проростання, середній насінний спокій ДСТУ 8558:2015 (DSTU 8558:2015, 2017) окремо із зразків різного географічного походження.
Для визначення впливу температури на схожість, пророщування насіння проводили на вологому ложі за двох температурних режимів: $+15 \ldots 20{ }^{\circ} \mathrm{C} \mathrm{i}+21 \ldots 25^{\circ} \mathrm{C}$ зі змінними температурами (ніч - мінімальна, день максимальна). За максимальних температур $\left(+20{ }^{\circ} \mathrm{C}\right.$ i $+25{ }^{\circ} \mathrm{C}$ ) подавали світло інтенсивністю 800 лк впродовж 8 год. Для встановлення впливу тривалості намочування насіння на показники схожості дослідження виконували в таких варіантах:

- намочування насіння у воді 3 температурою $+20{ }^{\circ} \mathrm{C}$ тривалістю 48 год;

- намочування насіння у воді 3 температурою $+20{ }^{\circ} \mathrm{C}$ тривалістю 24 год;

- без попереднього намочування (контроль).

Облік пророслого насіння проводили на $3,5,7,10$, 14 дні спостережень. Енергію проростання визначали на 7 день, а схожість - на 14 день спостережень.

Результати дослідження та обговорення. Вивчення біометричних показників плодів та насіння рослин різного географічного походження допомагає виявити мінливість та простежити залежність між розмірами плодів, що сформувались у регіонах із різними грунтово-кліматичними умовами та тривалістю вегетаційного періоду. Після формування зразків насіння, одержаного із заготовлених плодів павловнії повстистої, визначали масу 1000 насінин різного географічного походження. Оскільки маса 1000 насінин павловнії становить до 1 г, то для визначення цього показника, згідно з ДСТУ 5036:2008, відраховували і зважували одну пробу 3 500 насінин із подальшим множенням їхньої маси на 2. Дослідження проводили у 4-разовій повторності (табл. 1).

Табл. 1. Біометричні показники плодів на насіння павловнії повстистої різного географічного походження

\begin{tabular}{|c|c|c|c|c|c|c|c|c|c|c|c|}
\hline \multicolumn{3}{|c|}{ Діаметр (ширина) плоду } & \multicolumn{3}{|c|}{ Довжина плоду } & \multicolumn{3}{|c|}{ Маса свіжозібраного плоду } & \multicolumn{3}{|c|}{ Маса 1000 насінин } \\
\hline $\begin{array}{c}X_{c} \pm m_{x} \\
\text { (Limit), MM }\end{array}$ & $V, \%$ & $p, \%$ & $\begin{array}{c}X_{c} \pm m_{x} \\
\text { (Limit), MM }\end{array}$ & $V, \%$ & $p, \%$ & $\begin{array}{c}X_{c} \pm m_{x} \\
\text { (Limit), } \Gamma \\
\end{array}$ & $V, \%$ & $p, \%$ & $\begin{array}{c}X_{c} \pm m_{x} \\
\text { (Limit), } \Gamma\end{array}$ & $V, \%$ & $p, \%$ \\
\hline \multicolumn{12}{|c|}{ м. Одеса } \\
\hline $\begin{array}{c}28,71^{ \pm 0,13} \\
(24-32)\end{array}$ & 6,31 & 0,5 & $\begin{array}{c}38,51^{ \pm 0,13} \\
(34-41)\end{array}$ & 4,60 & 0,3 & $\begin{array}{c}2,33^{ \pm 0,01} \\
(2,1-2,5)\end{array}$ & 4,53 & 0,4 & $\begin{array}{c}0,134^{ \pm 0,001} \\
(0,132-0,138)\end{array}$ & 2,14 & 0,7 \\
\hline \multicolumn{12}{|c|}{ м. Мукачево } \\
\hline $\begin{array}{c}27,75^{ \pm 0,15} \\
(22-31)\end{array}$ & 7,76 & 0,5 & $\begin{array}{l}37,6^{ \pm 0,11} \\
(33-40)\end{array}$ & 4,19 & 0,3 & $\begin{array}{c}1,76^{ \pm 0,01} \\
(1,5-2,1)\end{array}$ & 8,22 & 0,6 & $\begin{array}{c}0,123^{ \pm 0,001} \\
(0,120-0,125)\end{array}$ & 1,69 & 0,8 \\
\hline \multicolumn{12}{|c|}{ м. Львів } \\
\hline $\begin{array}{c}23,44^{ \pm 0,3} \\
(15-27)\end{array}$ & 18,34 & 1,3 & $\begin{array}{c}34,15^{ \pm 0,34} \\
(21-38)\end{array}$ & 14,11 & 1,0 & $\begin{array}{c}1,44^{ \pm 0,02} \\
(0,8-1,7)\end{array}$ & 22,54 & 1,4 & $\begin{array}{c}0,107^{ \pm 0,002} \\
(0,110-0,107)\end{array}$ & 4,21 & 1,9 \\
\hline
\end{tabular}

Примітка: $X_{c}$ - середнє арифметичне значення; $m_{x}-$ помилка середнього значення; $V$ - коефіцієнт варіації; Limit - крайні варіанти середніх значень; $p$ - точність досліду.

Аналіз даних табл. 1 свідчить про однорідність вибірок досліджуваних показників. Варто зазначити, що плоди походжень з Одеси та Мукачева мають незначну варіацію за всіма досліджуваними показниками. У плодів походженням зі Львова спостерігаємо середню варіацію за розмірами плоду та значну варіацію за їх масою. Це, на наш погляд, пов'язано з менш сприятливими кліматичними умовами для формування та росту плодів павловнії, що зростає у Львові. Варто зауважити, що за всіма середніми показниками простежуємо зростання визначених величин зразків плодів, одержаних 3 Одеси, до зразків, заготовлених у Львові. Найменше, поміж трьох досліджуваних походжень, змінюється довжина плодів, а найбільше - їхня маса. Визначена маса одного плоду значно відрізняється $(+62 \ldots+76 \%)$ від даних, зазначених у літературних джерелах - 0,55 г (Kokhno, Kurdiuk, Dudyk et al., 1991). Аналіз даних маси 1000 насінин свідчить про зменшення маси насіння у рослин, що зростають у регіоні з коротшою тривалістю періоду вегетації (м. Львів). Визначені нами показники маси насіння доцільно брати до уваги під час уточнення норм висіву насіння різного географічного походження у розсадниках.

За температурного режиму пророщування $+20 \ldots 25$ ${ }^{\circ} \mathrm{C}$ визначили технічну схожість насіння павловнії повстистої, що варіює в межах від 88 до $99 \%$ і є дещо вищою від наведеного у літературних джерелах (Kokhno, Kurdiuk, Dudyk et al., 1991) показника, незалежно від географічного походження (табл. 2). Причому найвище значення показника схожості у всіх варіантах дослідження у насіння з Львівської обл., які перевищують аналогічні показники насіння з Одеси і Мукачева на 6-7 \%.

Істотний вплив на схожість насіння має попереднє намочування, тривалість якого корелює 3 показниками технічної схожості. Під час намочування насіння у воді на 48 год відбувається збільшення схожості на 4-5 \%, у 
разі намочування на 24 год - на 1-3\%, порівняно 3 контролем (без намочування). Ще більше впливає попереднє намочування на швидкість проростання насіння. Так, енергія проростання насіння збільшується на 10 $40 \%$ і на 8-27\% (залежно від походження) за попереднього намочування відповідно на 48 год і 24 год. Загалом найвищою швидкістю і дружністю проростання характеризується насіння південного походження (м. Одеса), за сім днів спостережень проросло від 84,3 до 92,3\% від усього пророслого насіння. Тільки насіння цього походження розвинуло здорові нормально розвинені корінці вже на третій день спостережень. На наш погляд, відбувається кореляція швидкості проростання $з$ масою насінини, адже важче насіння (зокрема походження м. Одеса) має більший запас поживних речовин і спроможне до швидшого росту та розвитку зародка.

Табл. 2. Результати визначення показників схожості насіння павловнії повстистої за температурного режиму пророщування $+21 . .25^{\circ} \mathrm{C}$

\begin{tabular}{|c|c|c|c|c|c|c|c|c|c|c|}
\hline \multirow{4}{*}{\multicolumn{2}{|c|}{$\begin{array}{l}\text { Показник } \\
\text { схожості }\end{array}$}} & \multicolumn{9}{|c|}{ Походження насіння } \\
\hline & & & \multicolumn{3}{|c|}{ м. Мукачево } & \multicolumn{3}{|c|}{ м. Львів } \\
\hline & & \multicolumn{9}{|c|}{$\begin{array}{c}\text { тривалість намочування у воді перед закладан- } \\
\text { ням насіння на пророщування, год }\end{array}$} \\
\hline & & 0 & 24 & 48 & 0 & 24 & 48 & 0 & 24 & 48 \\
\hline \multirow{4}{*}{$\begin{array}{l}\text { Енергія } \\
\text { пророс- } \\
\text { тання, \% }\end{array}$} & $X$ & & & & & & & & 37,8 & 0 , \\
\hline & & & & 1,4 & & & & & 0,9 & \\
\hline & $\bar{V}$ & 2,27 & 2,06 & 3,33 & & & & & 4,52 & $t, 9$ \\
\hline & $p$ & 1,13 & 1,03 & 1,66 & & & 1,2 & & 2,26 &, 4 \\
\hline \multirow{4}{*}{$\begin{array}{c}\text { Техніч- } \\
\text { на схо- } \\
\text { жість, \% }\end{array}$} & $X_{c}$ & 89 & 90 & 93 & 87,8 & 90 & 93 & 4,8 & 96,8 & 8 , \\
\hline & $m_{x}$ & 0,8 & 1,9 & 1,5 & 1,5 & & 1,5 & 9 & 1 & 0,6 \\
\hline & $V$ & 1,83 & 4,16 & 3,17 & 3,53 & 2,75 & 3,17 & 1,8 & 2,13 & 1,2 \\
\hline & $p$ & 0,92 & 2,08 & 58 & & & 1,58 & 0,9 & 1,07 & 0,6 \\
\hline \multirow{4}{*}{$\begin{array}{c}\text { Абсо- } \\
\text { лютна } \\
\text { схо- } \\
\text { жість, \% }\end{array}$} & $X_{c}$ & & 90 & 94,5 & & & 93 & & 97 & 99 \\
\hline & & 1,2 & 1,2 & & & & ,4 & & 0,7 & 0, \\
\hline & $x$ & 2,63 & 2,72 & & & & 0,88 & & 1,46 & 0, \\
\hline & $p$ & & & & & &, 44 & & 0,73 & 0,2 \\
\hline \multicolumn{2}{|c|}{$\begin{array}{c}\text { Середній } \\
\text { насінний } \\
\text { спокій, днів }\end{array}$} & 7 , & 6,4 & 6,4 & 10,7 & 10 & 9,1 & 10,1 & 8,9 & 8, \\
\hline
\end{tabular}

Примітка: $X_{c}-$ середнє арифметичне значення; $m_{x}-$ помилка середнього значення; $V$ - коефіцієнт варіації, \%; $p-$ точність досліду \%.

Показник середнього насінного спокою також характеризує швидкість проростання насіння. Для насіння, зібраного в Одесі, середній насінний спокій $\epsilon$ найменший і становить від 6,4 до 7,3 днів, що свідчить про дуже високу швидкість проростання насіння. Насіння з Мукачева характеризується найменшою швидкістю проростання від 9,1 до 10,7 днів, що в 1,4 раза довше, ніж у насіння з Одеси. Швидкість проростання насіння, зібраного у Львові, займає проміжну позицію серед трьох походжень.

Досліджуючи непроросле насіння, на 14 день спостережень виявили в ньому порожнє (8,3-20,0 \% від загальної кількості непророслого насіння), загниле $(20,0$ $36,4 \%)$ і здорове насіння (54,5-100 \%), що дало змогу визначити абсолютну схожість. Незначна кількість порожнього насіння не має істотного впливу на показник абсолютної схожості. У чотирьох із дев'яти варіантів дослідження абсолютна схожість не відрізняється від технічної, у решти варіантів - перевищує технічну схожість тільки на $1 \%$.

У виробничих умовах достатньо важко підтримувати температурний режим понад $+20{ }^{\circ} \mathrm{C}$ у холодну пору року. Дослідження впливу зменшення температури на схожість насіння проводили за температурного режиму
$+15 \ldots 20{ }^{\circ} \mathrm{C}$, який відповідає температурному режиму теплиць (на початку весни) та виробничих приміщень, у яких проводять попередню перевірку посівних якостей насіння (табл. 3).

Табл. 3. Результати визначення показників схожості насіння павловнії повстистої за температурного режиму пророщування $+15 \ldots 20{ }^{\circ} \mathrm{C}$

\begin{tabular}{|c|c|c|c|c|c|c|c|c|c|c|}
\hline \multirow{4}{*}{\multicolumn{2}{|c|}{$\begin{array}{l}\text { Показник } \\
\text { схожості }\end{array}$}} & \multicolumn{9}{|c|}{ Походження насіння } \\
\hline & & \multicolumn{3}{|c|}{ м. Одеса } & \multicolumn{3}{|c|}{ м. Мукачево } & \multicolumn{3}{|c|}{ м. Львів } \\
\hline & & \multicolumn{9}{|c|}{$\begin{array}{c}\text { тривалість намочування у воді перед закладан- } \\
\text { ням насіння на пророщування, год }\end{array}$} \\
\hline & & 0 & 24 & 48 & 0 & 24 & 48 & 0 & 24 & 48 \\
\hline \multirow{4}{*}{$\begin{array}{c}\text { Енергія } \\
\text { пророс- } \\
\text { тання, \% }\end{array}$} & $X_{c}$ & ( & $\overline{5,0}$ & & & & , & & $\mathbf{0}$ & $\mathbf{0}$ \\
\hline & $m_{x}$ & & 0,4 & & & & & & & \\
\hline & $V$ & - & 16,33 & 90 & & & & & & - \\
\hline & $p$ & & 16 & 3,45 & & & & & & \\
\hline \multirow{4}{*}{$\begin{array}{c}\text { Технічна } \\
\text { схо- } \\
\text { жість, \% }\end{array}$} & $X_{c}$ & 65,8 & 69,3 & $\mathbf{7 3 , 3}$ & 66 & 67,8 & 69,8 & 73 & 74,8 & 78,8 \\
\hline & $\overline{m_{x}}$ & 0,9 & 0,9 & 0,9 & 0,8 & 1 & 0,9 & 0,4 & 0,9 & 0,9 \\
\hline & V & & 2,47 & 2,33 & & 3,04 & 2,45 & 1,12 & 2,28 & \\
\hline & $p$ & & 1,23 & 1,17 & & & 22 & 0,56 & 1,14 & \\
\hline \multirow{4}{*}{$\begin{array}{l}\text { Абсолют- } \\
\text { на схо- } \\
\text { жість, \% }\end{array}$} & $X_{c}$ & 66,3 & 70 & 74 & 67,5 & 68,5 & $\mathbf{7 0 , 8}$ & 74,3 & 76 & \\
\hline & $m_{x}$ & & 0,8 & 0,7 & & 1,3 & 0,9 & 0,6 & 0,8 & 0 \\
\hline & $V$ & 2,58 & 2,33 & 1,91 & 3,08 & 3,86 & 2,68 & 1,69 & 2,15 & 2,1 \\
\hline & $p$ & 1,29 & 1,17 & 0,96 & 1,54 & 1,93 & 1,34 & 0,85 & 1,07 & 1,0 \\
\hline \multicolumn{2}{|c|}{$\begin{array}{l}\text { Середній } \\
\text { насінний } \\
\text { спокій, днів }\end{array}$} & 13,9 & 12,6 & 12,6 & 14,2 & 14 & 13,9 & 14,5 & 14,4 & 14,3 \\
\hline
\end{tabular}

Примітка: $X_{c}$ - середнє арифметичне значення; $m_{x}-$ помилка середнього значення; $V$ - коефіцієнт варіації, $\% ; p-$ точність досліду \%.

Загалом зниження температури пророщування насіння павловнії повстистої призводить до зниження всіх показників схожості. Так, технічна схожість насіння змінюється в межах 66-79 \%, що є нижчим від зазначених у літературі (Kokhno, Kurdiuk, Dudyk et al., 1991) показників. Порівняно 3 пророщуванням за температури $+20 \ldots 25{ }^{\circ} \mathrm{C}$ зниження досліджуваного показника становить 20-23\% залежно від варіантів досліду. Найвище значення технічної схожості в насіння зі Львова (73-79 \%), найнижче - у насіння з Мукачева (66-70 \%), що відповідає результатам попередніх досліджень.

Попереднє намочування насіння за нижчих температур також позитивно впливає на схожість насіння. Зростання показника технічної схожості, залежно від походження насіння, становить 4-7 \% (48 год намочування) та 2-3\% (24 год), порівняно 3 контролем.

Достеменно встановлено, що за температурного режиму $+15 \ldots 20{ }^{\circ} \mathrm{C}$ значно сповільнюється процес проростання насіння. Енергія проростання дорівнює $0 \%$ у семи із дев'яти варіантів досліду. Тільки насіння південного походження (м. Одеса) характеризується енергією проростання 5 і 7 \% за попереднього намочування відповідно 24 і 48 год. Тривалість середнього насінного спокою істотно збільшується (12,6-14,5 днів), що 1,32,0 раза більше від аналогічних варіантів досліду за температури $+20 \ldots 25^{\circ} \mathrm{C}$.

Висновки. Насіння павловнії повстистої характеризується високою технічною схожістю незалежно від географічного походження.

Для збільшення швидкості проростання насіння i підвищення схожості доцільно дотримуватися температурного режиму $+20 \ldots 25{ }^{\circ} \mathrm{C}$. Зниження температури спричиняє зменшення схожості. Середній насінний спокій у 1,3-2,0 раза більший за температур $+15 \ldots 20{ }^{\circ} \mathrm{C}$.

Попереднє намочування насіння істотно впливає на показники схожості: збільшується технічна й абсолют- 
на схожість, швидкість проростання насіння, зменшується середній насінний спокій. Збільшення тривалості намочування (від 24 до 48 год) корелює зі збільшенням технічної схожості та енергії проростання насіння.

В умовах Одеської обл. павловнія повстиста формує більші плоди, маса яких переважає масу плодів із Закарпатської та Львівської областей на 24 та $38 \%$. Насіння цього походження $є$ важчим і характеризується більшою швидкістю проростання та дружністю появи сходів.

Загалом досліджуване насіння трьох походжень характеризується високими посівними якостями, яке можна використовувати для вирощування садивного матеріалу $з$ подальшим застосуванням у плантаційному лісовирощуванні.

\section{Перелік використаних джерел}

Bojnansky, V., \& Fargasova, A. (2007). Atlas of seeds and fruits of central and east-European flora: The Carpathian Mountains Region. Berlin: Springer, 1046 p.

Bonner, F. T., \& Karrfalt, R. P. (Eds). (2008). Storage of seeds. The woody plant seed manual, 727, 772-773. Washington (DC): USDA Forest Service Agriculture Handbook.

DSTU 5036:2008. (2009). Nasinnia derev ta kushchiv. Metody vidbyrannia prob, vyznachennia chystoty, masy 1000 nasinyn ta volohosti. [chynnyi vid 2009.01.01]. Kyiv: Derzhspozhyvstandart Ukrainy, 45 p. (Natsionalnyi standart Ukrainy). [In Ukrainian].
DSTU 8558:2015. (2017). Nasinnia derev i kushchiv. Metody vyznachannia posivnykh yakostei (skhozhosti, zhyttiezdatnosti, dobroiakisnosti). [chynnyi vid 2017.01.01]. Kyiv: Derzhspozhyvstandart Ukrainy, 91 p. (Natsionalnyi standart Ukrainy). [In Ukrainian].

Hakan, A. M., \& Kol, H. S. (2010). Some technological properties and uses of paulownia (Paulownia tomentosa Steud.) wood. Journal of Environmental Biology Triveni Enterprises. Lucknow (India).

Hugo, D. Z. V., Bocanegra, J. A. J., Torres, F. P., Pleguezuelo, C. R., R., \& Biomass, J. R. F. M. (2013). Yield Potential of Paulownia Trees in a Semi-Arid Mediterranean Environment (S Spain). International Journal of Renewable Energy Research, 3(4), 23-31.

Icka, P., Damo, R., \& Icka, E. (2016). Paulownia tomentosa, a Fast Growing Timber. Annals "Valahia" University of Targoviste - Agriculture, 10(1), 14-19.

Kokhno, I. A., Kurdiuk, A. M., Dudik, N. M., Kokhno, N. A. (Ed.), et al. (1991). Plody i semena derevev $i$ kustarnikov, kultiviruemykh $v$ Ukrainskoi SSR. Kiev: Nauk. dumka, 320 p. [In Russian].

Kolesnikov, A. I. (1974). Dekorativnaia dendrologiia. Moscow: Lesnaia promyshlennost, 704 p. [In Russian].

Kumarmangalam, Y. N., Vaidya, B. N., Henderson, K., Lee, J. F., Stewart, W. M., Dhekney, S. A., \& Joshee, N. (2013). A Review of Paulownia Biotechnology: A Short Rotation, Fast Growing Multipurpose Bioenergy Tree. American Journal of Plant Sciences, 4, 2070-2082.

Woods, V. B. (2008). Paulownia as a novel biomass crop for Northern Ireland? Agri-Food and bioscience Institute, 7, 141-146.

Zhu, Z.-H., Chao, C.-Ju, Lu, X.-Yu, \& Gao, X. Y. (1986). Paulownia in China: cultivation and utilization. Published by Asian network for biological sciences and international development research centre.

A. P. Ivanyuk, T. I. Harachko, E. P. Ivantsov Ukrainian National Forestry University, Lviv, Ukraine

\section{GERMINATION OF SEEDLINGS AND BIOMETRIC PARAMETERS OF FRUITS OF PAULOWNIA TOMENTOSA STEUD. OF DIFFERENT GEOGRAPHICAL ORIGIN}

Paulownia tomentosa Steud. - rapid growing wood breed, capable to regenerate many times by sprout shoots after the cutting of tree and accelerating the growth of subsequent generations, it is a perspective for plantation cultivation in Ukraine. The purpose of the work is to investigate the germination quality of the seeds of the Paulownia tomentosa and the biometric indicators of the fruits and seeds, depending on the geographical origin of the trees, to evaluate the possibility of using the zoned seeds for the cultivation of high quality planting material. Biometric indicators were determined on the basis of measurements of the size of the fruits obtained in different geographical regions of Ukraine (Lviv, Transcarpathian and Odessa oblasts). To determine the effect of temperature on crop quality, germination of seeds was carried out at two temperature regimes: $++15 \ldots 20^{\circ} \mathrm{C}$ and $+21 \ldots 25^{\circ} \mathrm{C}$. To determine the effect of the duration of pre-wetting on similarity indicators, seeds were soaked in water with a temperature of $+20^{\circ} \mathrm{C} 24$ and 48 hours.

In the conditions of the Odessa region, Paulownia tomentosa forms larger fruits, the weight of which is dominated by a mass of fruits from the Transcarpathian and Lviv regions by 24 and $38 \%$. Seeds of this origin are heavier and are characterized by higher sprouting rates and the friendly appearance of seed germinations. In the temperature mode of sprouting $+20 \ldots 25^{\circ} \mathrm{C}$, the technical germination of the Paulownia tomentosa seeds varies from 88 to $99 \%$, regardless of geographical origin. At pre-soaked seeds in water for 48 hours are increasing of germination by 4-5\%, when soaked for 24 hours - by 1-3\% compared to the control (without soaking). The energy of seed germination is increased by $10-40 \%$ and by $8-27 \%$. In the seeds harvested in Odessa average of seed rest is the smallest and ranges from 6.4 to 7.3 days, which indicates a very high seed germination rate. The decrease in the temperature of germination of the Paulownia tomentosa seeds leads to a decrease in all similarity indicators. The technical germination of the seeds varies in the range of 66-79\%; compared with the germination at a temperature of $+20 \ldots 25{ }^{\circ} \mathrm{C}$ decreases in the studied index is 20-23\%. Preliminary soaking of seedlings at lower temperatures also has a positive effect on seed germination. Seeds of Paulownia tomentosa are characterized by a high technical germination, regardless of geographical origin. The temperature decreasing significantly slows the seed germination process and causes a decrease in germination indexes. The increase in the duration of the prewetting is due to an increase in the technical germination and energy of seed germination. In general, the studied seed of three origins is characterized by high crop qualities and can be used for growing seedling material.

Keywords: Paulownia tomentosa Steud.; seed; fruits; germination energy; technical germination; absolute germination, average of seed rest. 